\title{
Corporate Social Responsibility Performance and Level of Internationalization: Example from an Emerging Country Context
}

\author{
Ozan Ağlargöz, Abdullah Yağız Akgül \\ Anadolu University/Faculty of Economics and Administrative Sciences
}

\begin{abstract}
The paper approaches the broader discussion between corporate social performance and corporate financial performance from the internationalization perspective. This paper aims to scrutinize the relationship between corporate social responsibility performance and the degree of internationalization of businesses operating in Turkey. The initial theoretical trigger of the paper is LLL-Framework of internationalization. Fortune 500 list published by Fortune Turkey was used for this aim. The top hundred businesses in this list were examined, and fifty of these hundred businesses were included in the study because they published at least one of the types of reports required for the assessment of corporate social responsibility performance. Corporate social responsibility performance value of these businesses was measured by using the KLD index. The degree of internationalization is calculated by using export figures. Regression analysis was conducted, and the findings of the study revealed a high and positive correlation between these two variables for the selected sample.
\end{abstract}

Keywords: corporate social responsibility; emerging country; KLD index; sustainability; internationalization 